\title{
SZÉNHIDROGÉN-SZÁLLÍTÓ CSŐVEZETÉKEK MEGHIBÁSODÁSÁNAK JAVÍTÁSI MÓDSZEREI
}

\author{
Demeter Andrea
}

\section{Bevezetés}

A szénhidrogén-szállító csőtávvezetékeken üzem közben hibák keletkezhetnek. Az elöforduló hibák csoportositását, elemzését elvégezve [1], vizsgálva az egyes hibatípusok veszélyességét [2] megállapítható, hogy a megjelenő hibák típusaitól és veszélyességétől függő javítási módszerek kifejlesztésére, alkalmazhatósági feltételeik kidolgozására nagy hangsúlyt célszerủ fordítani.

\section{Csővezetékeken alkalmazott javítási módszerek}

A csővezetékeket üzemeltetők jól követhető metodikát alkalmaznak részben a hibagyanús helyek kezelésében, feltárásában, részben a megfelelő javítási megoldások alkalmazásában [3,5]. A kidolgozott metodikák mindenkor alkalmazkodnak az adott csővezetékeket üzemeltetök sajátos körülményeihez, amely körülmények viszont nem egységesek és egyesithetök, így egy - egy rendszer egészében vagy részleteiben nem, vagy csak kísérletekkel leellenörzött, a feltételrendszereket pontosító vizsgálatok elvégzése után vehető át. Tanulmányozva az e témakörben a megjelent hazai illetve külföldi publikációkat az megállapítható, hogy a karbantartási, javitási módszerek tökéletesítésére, újabb módszerek, technológiák kidolgozását vonta maga után. Az 1. ábra egy hibagyanús hely kezelésénak folyamatát mutatja be. Az algoritmuson belül kiemeltük a javítási módszereket, amelyeket a késöbbiekben részletesen mutatunk be [9]. 


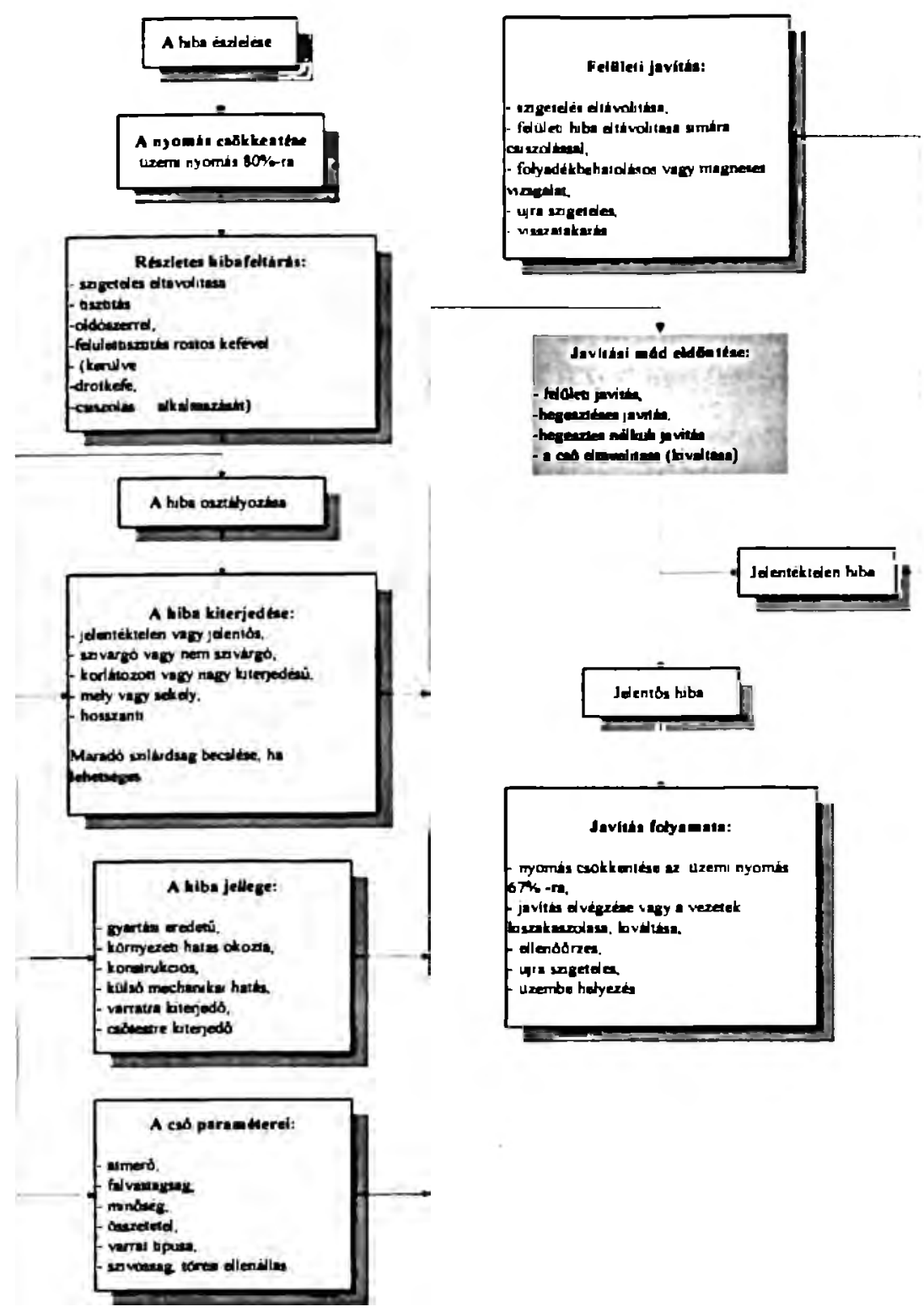

1. ábra

A hibagyanús hely kezelésének folyamata

\section{Hibahely javítása felületi kiigazítással}

Jelentéktelen illetve közepes méretü hibák esetén gyakran alkalmazott javítási módszer a hibás felületek kiigazítása [5,6]. Ennek célja a hibás felület helyi hibáinak éles átmeneteit különféle felületmegmunkáló módszerekkel. A javítás kivitelezése során a helyi hibák kiigazításával sima, hibamentes felület, egyenletes falvastagságátmenet alakítható ki. 


\section{Hibahely javítása helyi felhegesztéssel}

Jelentéktelen, illetve közepes méretủ hibák esetén alkalmazott megoldás a helyi hibák úgynevezett helyi felhegesztéses javítása $[3,4,6]$. Az így javitható hibák a cső anyagának minöségével megegyezö minőségű hegesztőanyag alkalmazásával helyi felhegesztéssel kerülnek javításra $[1,4]$ ).

\section{Hibahely javítása hegesztéses foltozással}

Gyakran alkalmazott megoldás közepes méretű karcok, horpadások, általános illetve helyi korróziós hibahelyek javitására a helyileg alkalmazott hegesztéses foltozásos technológia. Az elökészített hibahelyet a csö anyagával megegyező, a hiba méretétöl függő méretü és kialakítású, a csö geometriájához igazodó folt felhegesztésével javítják [4].

\section{Hibahely javítása két félből álló hegesztett csőszeletes foltozással}

Üzemelő csővezetékeken előforduló különféle hibák (geometriai, fémveszteséggel járó, anyagfolytonossági hiányok okozta) javitására elterjedten alkalmazott módszer különféle geometriai kialakítású hegesztett csöszeletes foltozással végrehajtott úgynevezett javítóhüvelyek alkalmazása $[3,4$, 5, 6]. A hibák típusától, veszélyességétől függően különféle kialakitású javitóhüvelyek alkalmazásával találkozhatunk a csővezetékeket üzemeltető karbantartási, javítási gyakorlatban.

\section{Hibahely javítása csővezetékre felhegesztett leágazás elkészítésével}

Üzemelő csővezetékeken előforduló különféle nem szivárgó hibák (geometriai, fémveszteséggel járó, anyagfolytonossági hiányok okozta) javításra alkalmazható módszer lehet a nyomás alatt levő vezetékekre felhegesztett különféle kialakítású leágazás elkészítése $[3,4,5,7,8]$.

\section{Hibahely javítása epoxigyantával kitöltött köpeny alkalmazásával}

A módszer alkalmazható minden nem szivárgó csővezeték sérülésre és kiküszöböli a költséges javításokat. Az epoxigyantával töltött köpenyek tartós javítást biztosítanak a csővezeték meghibásodások széles körében, beleértve a homorulatokat, behorpadásokat, repedést és korróziót, valamint kiküszöbölik a költséges hegesztési és illesztési problémákat. A kijavítás költséges lehet, hogyha a megsérült csövet a termék áramlásának megszakitása nélkül kell kivágni. Az epoxigyantával töltött köpenyek kevésbé költséges és könnyen alkalmazható alternativát jelentenek a kivágással szemben. 


\section{Hibahely javítása Cloek Spring segítségével}

A hegesztés nélküli javítás egyik gyors és olcsó alternatívája az amerikai gyártmányú Clock Spring. A Clock Spring nem szivárgó sérülések esetén alkalmazható, amely nem más mint egy szálerősítésü mügyanta tekercs, amelyet ragasztóanyag felhordásával rögzítenek a sérült csőszakaszra, annak alapos megtisztítása után.

Irodalomjegyzék:

[1] Szakértői rendszer elemeinek kifejlesztése csővezetékek biztonságos üzemeltetésének megítélésére, C. melléklet, A csővezetéken előforduló hibák ME MTT, EK: 593006 sz. jelentés 1993.

[2] Szakértői rendszer elemeinek kifejlesztése csővezetékek biztonságos üzemeltetésének megítélésére, E. melléklet, Kísérleti csőszakaszok vizsgálata, ME MTT, EK: 593006 sz. jelentés, 1993.

[3] KIEFNER, I.F.: Criteria Set For Pipeline Repair. Oil and Gas Journal, Aug. 7. 1978. p. 104 - 118.

[4] ASME Guide for Gas Tramsmission and Distribution Piping Systems. ASME B 31.4 - 1989.

[5] Procedures For Inspection and Repair of Damaged Steel Pipelines Designed to Operate at Pressures Above 7 Bar. British Gas Engineering Standard BGC/PS/P11,1983.

[6] RONSKY, N.D. - TREFANENKO, B.: Inegrity Management, the Cost Effective Alternative. Pepeline Rehabilitation Seminar, January 28 - 31.,1992. Houston, Texas.

[7] Szakvélemény a Testvériség gázvezeték gyöngyösi leágazásánál bekövetkezett törésröl. NME, MTT, Szm 167 - XXIX - 20/80., 1983.

[8] Zárójelentés a nyomás alatti csővezetéken történő hegesztés kidolgozása témában. NME, MTT, Szm 188 - XXIX/84., 1985.

[9] DEMETER A. : Repairing methods of damaged hydro-carbon transporting pipelines. Ms.C thesis 1995. London, England.

Demeter Andrea Ph.D hallgató

Miskolci Egyetem/ Miskolc Egyetemváros 3515, Magyarország

Tel: 46/ 366-111 (17-90) 